FILOZOFIA

Roč. 74,2019 , č. 9

DOI: https://doi.org/10.31577/filozofia.2019.74.9.6

\title{
JE NEDOROZUMENIE MEDZI KOMPATIBILISTAMI A INKOMPATIBILISTAMI LEN VERBÁLNE?
}

TOMÁŠ KOLLÁRIK, Katedra logiky a metodológie vied, Filozofická fakulta Univerzity Komenského v Bratislave, Bratislava, SR

KOLLÁRIK, T.: Is Disagreement Between Compatibilists and Incompatibilists Merely Verbal?

FILOZOFIA, 74, 2019, No 9, pp. $768-784$

\begin{abstract}
The goal of this paper is to show that disagreement between compatibilists and incompatibilists about compatibility of free will with determinism is merely verbal, since although one side of the dispute claims that free will is compatible with determinism, whereas the other side denies it, they in fact ascribe to the expression „, free will“ a different meaning. One can thus accept both the compatibilist thesis as well as the incompatibilist thesis, as these two do not constitute a contradictory pair. My method consists in analysing the meaning of the phrase being an ability to do otherwise as a property of abilities and the meaning of the phrase having an ability to do otherwise as a property of agents. The outcome of conducted analysis enables me to make an unbiased comparison of necessary conditions which compatibilists and incompatibilists expect to hold if agents are to have the ability to do otherwise. It is shown, as expected, that these conditions are not the same.
\end{abstract}

Keywords: Ability - Ability to do otherwise - Determinism - Indeterminism Compatibilism - Incompatibilism - Free will

V rámci diskusie o zlučitel'nosti slobodnej vôle a determinizmu môžeme identifikovat' niekol'ko pozícií. Podla inkompatibilizmu slobodná vôl'a a determinizmus nie sú zlučitel'né, pretože ak majú mat' aktéri slobodnú vôl'u, musia mat' schopnost' konat' inak. A táto schopnost' nie je zlučitel'ná s determinizmom. Medzi inkompatibilistami sú takí, podl'a ktorých slobodná vôl'a existuje, a teda determinizmus je podl'a nich nepravdivý. A sú medzi nimi aj takí, ktorí tvrdia, že determinizmus je pravdivý, a preto neexistuje nič také ako slobodná vôla. Prví sa nazývajú libertariáni a druhí striktní inkompatibilisti.

Podl'a kompatibilizmu sú determinizmus a slobodná vôl'a zlučitel'né. V rámci kompatibilizmu môžeme rozlíšit takisto dve pozície. Jedna z nich nemá zvláštny dôvod nesúhlasit' $\mathrm{s}$ inkompatibilistami $\mathrm{v}$ tom, že schopnost' konat' inak nie je zlučitel'ná s determinizmom. Títo kompatibilisti však dodávajú, že takto pochopená slobodná vôla nie je nevyhnutná pre morálnu zodpovednost' a že existuje iný koncept slobodnej vôle, ktorý je 
relevantný pre morálnu zodpovednost'. ${ }^{1}$ Druhá pozícia kompatibilizmu tvrdí, že determinizmus je zlučitel'ný so schopnost'ou konat' inak. Prvý typ kompatibilistu nie je s inkompatibilizmom v priamom spore, pretože neodporuje, a ani nemá záujem odporovat' inkompatibilistickej téze, že schopnost' konat' inak je nezlučitel'ná s determinizmom. Iba dodáva, že existuje iný zmysel výrazu ,slobodná vôla“, ktorý je relevantný pre morálnu zodpovednost', a ked'že morálna zodpovednost' je to, na čom najmä záleží, tak si s týmto konceptom slobodnej vôle celkom dobre vystačíme. Zato druhý typ kompatibilizmu je s inkompatibilizmom v priamom spore, pretože tvrdí presne to, čo inkompatibilizmus zamieta, totiž že slobodná vôl'a a determinizmus sú zlučitel'né. Svedok tohto sporu môže l'ahko a z pochopitel'ných dôvodov nadobudnút' dojem, že jedna strana musí mat' pravdu. Ak je to tak, potom musia byt' závery jednej zo strán založené na nesprávnej argumentácii.

Ciel'om tejto práce je zaoberat' sa myšlienkou, že tieto dve pozície netvoria spor, respektíve, že ich spor existuje len na úrovni výrazov jazyka, ale nie na úrovni významu. Ked' budem d'alej hovorit' o kompatibilizme, vždy budem mat' na mysli kompatibilizmus, ktorý je s inkompatibilizmom v priamom spore.

Postup práce bude nasledovný. Najprv prijmeme neformálne vymedzenie determinizmu. Potom uvedieme Peter van Inwagenovu definíciu, ktorú formuloval, aby mohol vzápätí uviest' dosial' najznámejšiu a najvplyvnejšiu podobu inkompatibilistického argumentu, ktorý patrí do rodiny argumentov následku.

V d’alšej časti práci sa pozrieme na jednotlivé podoby kompatibilizmu a ich odpovediam na argument následku. Na tomto základe formulujem všeobecnú kompatibilistickú obhajobu tézy, že schopnost' konat' inak je zlučitel'ná s determinizmom. Potom sa budem zaoberat' analýzou významu výrazu „byt' schopnost'ou konat' inak“ ako vlastnost'ou schopností, a tiež významom výrazu „mat' schopnost' konat' inak“ ako vlastnost'ou aktérov. Až po definovaní výrazu „,byt' schopnost'ou konat' inak“ sa môžeme pýtat' na podmienky, za ktorých je pravda, že aktér má schopnost' konat' inak. Ďalej určím nevyhnutné podmienky, ktoré musia byt' splnené, aby mal aktér schopnost' konat' inak a porovnám, čo k týmto podmienkam pridávajú kompatibilisti, respektíve inkompatibilisti. Záverom práce konštatujem, že kompatibilisti a inkompatibilisti majú iný pojem schopnosti konat' inak a preto ich tézy netvoria spor.

\section{Definícia determinizmu a argument následku}

Na úvod práce treba povedat', že podrobnejší komentár k determinizmu, respektíve $\mathrm{k}$ jeho definovaniu priložíme neskôr. ${ }^{2}$ Zatial' si vystačíme s neformálnym priblížením

${ }^{1}$ Pozri napríklad: Harry G. Frankfurt (1969), alebo Martin Fischer (2007).

${ }^{2} \mathrm{~V}$ tejto práci nie je priestor na to, aby sme sa venovat' problémom súvisiacim s definovaním determinizmu. Pritom ide o vel'mi dôležitú, a často podceňovanú tému, čo v závere práce stručne doložíme. Keby mal čitatel' záujem dozvediet' sa o tejto oblasti viac, môže to urobit' napríklad v článkoch Marka (2017) a Müllera a Placeka (2018). Marko ukazuje, že v súčasnej literatúre sa nezriedka jedna 
podl'a ktorého platí, že ak je svet deterministický, tak sú jeho minulost' a prítomnost' zlučitel'né len s jednou jedinou budúcnost'ou. Takýto opis determinizmu je výhodný v tom, že je vel'mi jednoduchý a názorný a preto je l'ahké usúvzt'ažnit' ho so znepokojením libertariánov. Títo filozofi vychádzajú z predpokladu, že slobodný aktér má na výber a to, čo si vyberie, závisí vo vel'kej miere od neho. Obava týchto autorov by už teraz mala byt' čitatel'ovi zrejmá - ako si môže aktér vyberat' v deterministickom svete, ked' je v ňom každé jeho konanie predurčené, a to nezávisle od jeho vôle? V deterministickom svete je vždy len jedna jediná cesta a ak sa nejaký aktér, ktorý ho obýva, nazdáva, že je slobodný, tak má subjektívny dojem - ilúziu, respektíve zdanie, ktoré však nemá nič do činenia so skutočnost’ou.

Definícia determinizmu Petra van Inwagena je šitá na mieru pre potreby jeho argumentu následku. To je hlavný dôvod, prečo ju tu citujeme. Sama definícia pozostáva $\mathrm{z}$ dvoch bodov:

a) Pre každý okamih času jestvuje propozícia, ktorá vyjadruje stav sveta $\mathrm{v}$ tomto čase.

b) Ak A a B sú lubovol'né propozície vyjadrujúce stav sveta v nejakých časových okamihoch, tak z konjunkcie A s fyzikálnymi zákonmi vyplýva B $(1975,186)$.

Definícia sa opiera o niekol'ko pojmov: pojem propozície, pojem fyzikálneho zákona, pojem stavu sveta $\mathrm{v}$ okamihu a pojem vyplývania. Neodvoláva sa na princíp kauzality, podl'a ktorého všetko, čo sa stane, má príčinu v nejakom predchádzajúcom stave. Existuje preto dobré vysvetlenie. Pojmy príčiny a účinku boli a sú predmetom častých kontroverzií. Keby definícia determinizmu bola formulovaná v týchto termínoch, mohlo by sa stat', že by sa kritická pozornost' autorov, ktorí nesúhlasia so záverom argumentu následku, presunula práve týmto smerom. To by znížilo účinnost' inkompatibilistovej argumentácie. Táto definícia je zároveň v súlade s naším neformálnym, a preto pomerne všeobecným vymedzením determinizmu. Predpokladajme, že nejaká propozícia o minulosti $H$ vyjadruje stav sveta v nejakom dávnom minulom okamihu $t$. A nech $\mathrm{v}$ našom svete platia prírodné zákony $L$. Potom je $\mathrm{z}$ bodu $\mathrm{b}$ ) zrejmé, že všetky propozície vyjadrujúce stav sveta v nasledujúcich okamihoch budú jednoznačne určené. Sú logickým dôsledkom konjunkcie $L$ a $H$.

koncepcia determinizmu označuje rôznymi názvami, respektíve že tie isté koncepcie sa označujú jediným názvom. Marko sa preto zaoberá konceptuálnou štruktúrou existujúcich koncepcií determinizmu a klasifikuje ich podl'a identifikovaných konceptuálnych elementov. Müller a Placek porovnávajú viaceré známe postupy definovania determinizmu. Výsledkom uplatnenia rôznych postupov sú neekvivalentné koncepty determinizmu, ktoré môžu viest' k rôznym odpovediam pri klasifikácii fyzikálnych teórií na deterministické, respektíve indeterministické. 


\section{Argument následku}

Van Inwagen uvádza argument opisom situácie, v ktorej sa rozhoduje o živote a smrti. Ak je niekto svedkom niečoho podobného, je len prirodzené, že k rozhodnutiu zaujme určitý morálny postoj. Vo van Inwagenovom príklade môže sudca čírym zdvihnutím ruky zabránit’ trestu smrti usvedčeného zločinca. Predpokladajme, že $P_{0}$ je propozícia vyjadrujúca stav sveta v nejakom okamihu $T_{0}$ dávno pred narodením sudcu $S$. Propozícia $P$ vyjadruje stav sveta v okamihu $T$ a je nezlučitel'ná s takým stavom vecí, v ktorom je pravda, že $S$ má zdvihnutú ruku v $T$. $L$ označuje konjunkciu prírodných zákonov do jednej propozície. argument následku postupuje takto:

1. Ak je determinizmus pravdivý, tak z konjunkcie $P_{0}$ a $L$ vyplýva $P$.

2. Ak by $S$ zdvihol ruku v $T$, tak by $P$ bola nepravdivá. ${ }^{3}$

3. Ak je 2. pravda, tak ak $S$ mohol zdvihnút' ruku v $T$, tak $S$ mohol spôsobit' nepravdivost' $P$.

4. Ak $S$ mohol spôsobit' nepravdivost' $P$ a ak z konjunkcie $P_{0}$ a $L$ vyplýva $P$, tak $S$ mohol spôsobit' nepravdivost' konjunkcie $P_{0}$ a $L$.

5. Ak $S$ mohol spôsobit' nepravdivost' konjunkcie $P_{0}$ a $L$, tak mohol spôsobit' nepravdivost' $L$.

6. Ale $S$ nemohol spôsobit' nepravdivost' $L$.

7. Ak je determinizmus pravdivý, tak $S$ nemohol zdvihnút' ruku v $T$ (van Inwagen 1975, 191)

A ked'že tento záver môžeme dosiahnut' pre l'ubovol'né konanie, respektíve propozíciu, tak platí, že ak je pravdivý determinizmus, vždy môžeme konat' iba tak, ako sme konali.

Ako som povedal, van Inwagenov argument následku vyvolal množstvo reakcií. Jedným z dôvodov je, že van Inwagen uvádza argument opisom situácie, v ktorej má sudca urobit' čosi, čo je v istom zmysle vel'mi jednoduché a bežné rozhodnút' sa medzi zdvihnutím a nezdvihnutím ruky. A argument sa končí záverom, že sudca na výber nemá. Ak má ruku na stole, tak ju ani nemohol zdvihnút'. Druhý dôvod, prečo argument následku vyvolal takú diskusiu, je to, o čom explicitne nehovorí - súvislost', o ktorej sú mnohí presvedčení, že medzi morálnou zodpovednost'ou a slobodnou vôl'ou je a podl'a ktorej platí, že aktér je za svoje správanie morálne zodpovedný, iba ak by mohol konat’ inak. Argument následku však

\footnotetext{
${ }^{3}$ Neskôr van Inwagen túto premisu mierne pozmenil: 2. Nie je možné, aby $S$ zdvihol v T ruku a P bola zároveň pravdivá (van Inwagen 1983, 70). Nazdávam sa, že posun vo význame druhej premisy je z hl'adiska podpory záveru irelevantný.
} 
vylučuje, že aktéri takúto schopnost' niekedy majú - ak je pravdivý determinizmus. Ako by mohol sudca niest' morálnu zodpovednost' za to, že nechal ruku na stole, ked' ju nemohol zdvihnút? A ako si mohol obžalovaný zaslúžit' trest smrti?

\section{Kompatibilisti a význam výrazu „môct"“}

Kompatibilisti odmietajú 4. bod argumentu následku. Zamietli to, že ak má sudca schopnost' zdvihnút' ruku, tak má schopnost' urobit' konjunkciu $H$ a $L$ nepravdivou. Preto sa zdá, že spor inkompatibilistov a kompatibilistov je sporom o význam výrazu „môct"“. A tento spor môžeme opísat' tak, že kompatibilisti a inkompatibilisti dávajú odlišné odpovede na otázku: Za akých podmienok strácajú aktéri svoje schopnosti?

Vít Punčochář (2017) je zástancom kompatibilistickej pozície, ktorá vychádza z podmienkovej analýzy (conditional analysis) schopností. Jej prvú formuláciu môžeme nájst' už v prácach novovekých filozofov ako Thomas Hobbes alebo David Hume. Podl'a podmienkovej analýzy má aktér schopnost' utekat' vtedy a len vtedy, ked' je pravda, že keby sa tak rozhodol, utekal by. Podl'a tejto analýzy mat' schopnost' znamená, že za určitých kontrafaktuálnych podmienok by táto schopnost' bola realizovaná. Je zaujímavé všimnút' si, ako podmienková analýza schopností nápadne pripomína analýzu dispozícií. Napríklad sklenený pohár má dispozíciu rozbit' sa vtedy a len vtedy, ak je pravda, že keby bol vystavený nejakým špecifickým podmienkam, rozbil by sa. Pod „špecifickými podmienkami“ si môžeme predstavit' napríklad to, že na pohár dopadol kameň, alebo že pohár spadol z určitej výšky na tvrdý objekt a podobne. Pri analýze dispozícií aj schopností sa používa kontrafaktuál a v oboch prípadoch sa predpokladá, že mat' dispozíciu / schopnost' znamená, že sú také podmienky, za ktorých by boli aktualizované. Pravda je, že všetky pozície kompatibilizmu, podl'a ktorých je schopnost' konat' inak zlučitel'ná s determinizmom, analyzujú schopnosti podobne ako dispozície. A niektorí, ako uvidíme, definujú schopnosti ako špecifický druh dispozícií.

Podmienková analýza bola predmetom mnohých presvedčivých kritík. Viaceré d’alšie kompatibilistické prístupy, ktoré tu zmienime, sa odlišujú od podmienkovej analýzy v tom, že ich analýza schopností je sofistikovanejšia a rafinovanejšia, čo je práve výsledok zohl’adnenia kritiky namierenej proti podmienkovej analýze.

Vít Punčochář (2017) kritizuje špekulatívne filozofie, ktorých závery smerujú proti niektorým bežným presvedčeniam. Ak sa nejaká špekulatívna filozofia proti nim stavia, tak je to dôvod pochybovat' o tejto filozofii, a nie o tom, čomu bežne veríme. Medzi tieto presvedčenia patrí aj to, že:

... existuje zmysel výrazu „môct”, v ktorom je pravdivá napríklad

11) Teraz som mohol zdvihnút pravú ruku 
ale nie veta

12) Teraz som mohol svojmu priatel'ovi telepaticky zaslat' nejaké informácie (Punčochář 2017, 614).

Predpokladajme, že argument následku je dokonalý a determinizmus je pravdivý. Ak je potom pravda, že aktér nezdvihol pravú ruku, ani nezaslal telepaticky nejaké informácie, tak potom nemal schopnost' urobit' ani jedno, ani druhé. No podl'a Punčochářa medzi týmito vetami významový rozdiel je a tkvie $\mathrm{v}$ tom, že zdvihnutie pravej ruky, a nie telepatické zaslanie informácií priatel'ovi, je v moci aktéra. Je význam výrazu „môct“" v ktorom mohol urobit’ jedno, ale nie druhé.

Neviem presne, proti komu je Punčochářova kritika namierená, ale je zrejmé, že výskyt tých, ktorých by sa mohla týkat', je vel'mi zriedkavý. Striktní inkompatibilisti síce zamietajú slobodnú vôl'u, ale všetci nezamietajú morálnu zodpovednost' (pozri napríklad Pereboom 2007). A libertarián by takisto nesúhlasil so stotožnením významu „môct"“ vo vetách 11 a 12, iba ak za predpokladu, že determinizmus je pravdivý. Libertarián zamieta determinizmus práve preto, lebo verí, že medzi uvedenými vetami odlišnost' je, respektíve že výraz „môct“" v nich má odlišný význam.

Z tejto klúčovej časti Punčochářovho textu sa dozvedáme, že podla kompatibilistov existuje význam výrazu „môct“", v ktorom aktéri majú schopnost' konat' inak ako konali, aj ked' je determinizmus pravdivý. A tento „význam výrazu môct', ktorý je relevantný z hl'adiska slobodnej vôle“ (tamže, 613-614) je môct'v zmysle schopnosti - ak som aj nezdvihol pravú ruku a nezaslal som priatel'ovi telepaticky informácie, tak prvé konanie je v mojej moci, a nie druhé.

Punčocháŕove slová sú ozvenou toho, čo začiatkom dvadsiateho storočia napísal George Edward Moore (1912).

Ráno som mohol prejst' mílu za dvadsat' minút', ale určite som nemohol zabehnút' dve míle za pät' minút'. V skutočnosti som neurobil ani jedno. Ale je číry nezmysel, aby fakt, že som neurobil ani jedno, odstránil rozdiel, ktorý vyjadrím, ked' poviem, že jedno bolo v mojej moci a druhé nie (Moore 1912, 206).

Ďalšiu pozoruhodný komentár k rôznym významom „môct““ nájdeme niekol'ko strán d’alej:

A teraz predpokladajme, že premisa tohto argumentu je pravdivá: že všetko má v skutočnosti svoju príčinu. Čo z toho v naozaj vyplýva? Zrejme všetko, čo z toho vyplýva, je, že v jednom zmysle „mohlo“ sa nič nemohlo stat' inak, ako sa stalo (tamže, 209). 
Moore v citovanej pasáži spomína argument v prospech (kauzálneho) determinizmu. A tvrdí, že ak je determinizmus pravdivý, tak v jednom zmysle slova „môct”“ sa nič nemohlo stat' inak, ako sa stalo. Čiže ked' som nezdvihol pravú ruku, tak som v istom zmysle ani nemohol zdvihnút pravú ruku. Ale je iný význam výrazu „môct“, v ktorom som mohol zdvihnút' ruku. A podl'a podmienkovej analýzy schopností to, že som mal schopnost' zdvihnút' ruku, znamená, že by som ju zdvihol, keby som sa ju rozhodol zdvihnút'. Sám fakt, že aktuálne zdvihnutie nebolo zlučitel'né s predchádzajúcim kauzálnymi podmienkami, je konzistentný s mojou schopnost'ou zdvihnút' pravú ruku, pretože analýza schopností má formu kontrafaktuálu a antecedent je pravdivý $\mathrm{v}$ takom možnom svete, $\mathrm{v}$ ktorom sú nepravdivé propozície opisujúce práve tie kauzálne podmienky, $\mathrm{v}$ dôsledku ktorých $\mathrm{v}$ aktuálnom svete $v$ istom zmysle slova nemôžem zdvihnút pravú ruku.

Z našich pozorovaní si zatial' môžeme zobrat' všeobecné poučenie, že kompatibilisti podmienkovej analýzy tvrdia, že o schopnosti nás nepripravuje ani fakt, že ich realizovanie je nezlučitel'né s aktuálnymi podmienkami. A zdá sa, že je pravda, že takto o schopnostiach bežne uvažujeme. To, že práve neplávam, ma predsa neoberá o schopnost' plávat'. A ak som práve na mieste, kde nie je voda, tak ani nemôžem plávat'. No ani to, že teraz nemôžem plávat', asi nepodporuje tvrdenie, že nemám schopnost' plávat'.

A k rovnakému záveru dochádzajú aj kompatibilisti porušenia prírodného zákona, respektíve zmeny minulosti. ${ }^{4}$ Túto pozíciu formulovali napríklad filozofi ako David Lewis (1981), Martin Fischer (1983) a John Turk Saunders (1986).

Lewis rozlišuje dve tézy o schopnostiach:

(Slabá téza) Som schopný urobit' niečo také, že ak by som to urobil, bol by porušený (prírodný, T. K.) zákon.

(Silná téza) Som schopný porušit prírodný zákon (Lewis 1981, 115).

Podl'a Lewisa si kompatibilista celkom dobre vystačí so slabou tézou. A táto téza v skutočnosti nepripisuje aktérom žiadne zázračné schopnosti. Slabá téza sa od silnej odlišuje najmä tým, že v slabej téze je vnorený kontrafaktuál. Podl’a tejto tézy má aktér v aktuálnom svete nejakú nerealizovanú schopnost', napríklad schopnost' zdvihnút' ruku, ked' ju má na stole. Ak by túto ruku zdvihol, tak by porušil prírodný zákon. No jeho ruka leží na stole, čo je skutočnost', ktorá ho nijako neoberá o schopnost' zdvihnút' ju. Čiže aktér má schopnosti, ktorých realizovanie by znamenalo vykonanie

${ }^{4}$ Toto je moje pracovné označenie pozície, ktorej sa budem v nasledujúcich riadkoch venovat'. Pokial' viem, nie je žiadny všeobecne akceptovaný názov. 
zázraku. Aktéri môžu urobit' niečo, čo v inom zmysle tohto slova urobit' nemôžu. A to je tvrdenie, ktoré nápadne pripomína postoj podmienkovej analýzy. Podmienková analýza sa od Lewisovho prístupu na prvý pohl'ad odlišuje v tom, že nehovorí nič o porušení prírodného zákona. A práve zmienka o porušení prírodného zákona môže pôsobit' trochu mätúco. Mohlo by sa zdat', že Lewis tvrdí, že zdvihnutie ruky v aktuálnom svete by bolo porušením prírodných zákonov, ktoré platia $\mathrm{v}$ aktuálnom svete. A to je bežný zmysel výrazu zázrak - urobit' niečo, čo nie je zlučitel'né s prírodnými zákonmi. Lewis však neverí na zázraky.

Ked' poviem, že sa vo $\mathrm{w}_{1}$ stal zázrak, tak tým myslím to, že boli porušené prírodné zákony. Ale všimnite si, že porušené zákony nie sú zákonmi sveta, v ktorom boli porušené. To je nemožné; nech je prírodný zákon čímkolvek, je prinajmenšom neporušenou regularitou. Výraz „zázrak“" používam na vyjadrenie vzt’ahu rôznych svetov. Zázrak vo w relatívne $\mathrm{k}$ svetu $\mathrm{w}_{0}$, je porušením zákonov $\mathrm{w}_{0}$ vo svete $\mathrm{w}_{1}$, ktoré sú nanajvýš takmer zákonmi sveta $\mathrm{w}_{1}$. Zákonov sveta $\mathrm{w}_{1}$, ak vôbec existujú, sa to netýka (Lewis, 1987, s. 44 - 45).

Čiže antecedent kontrafaktuálu vnoreného do slabej tézy je pravdivý v takom možnom svete, ktorého prírodné zákony sa odlišujú od prírodných zákonov aktuálneho sveta. A zákony aktuálneho sveta sú ,porušené“ v možnom svete, v ktorom je pravdivý antecedent kontrafaktuálu. Ako však vidíme, zákony žiadneho možného sveta neboli porušené $\mathrm{v}$ tomto ani inom možnom svete.

Ak je pravda, že $\mathrm{k}$ porušeniu prírodného zákona $\mathrm{v}$ bežnom zmysle nedochádza, tak sa nazdávam, že menej zavádzajúce znenie slabej tézy by mohlo byt' takéto:

(Slabá téza)* Som schopný urobit' niečo také, že ak by som to urobil, prírodné zákony by boli iné, ako sú.

Podl'a tejto formulácie slabej tézy je vnorený antecedent pravdivý $\mathrm{v}$ takom možnom svete, $\mathrm{v}$ ktorom sú iné prírodné zákony ako v aktuálnom svete. Pozmenené znenie tézy tiež nevyvoláva potrebu, ktorú vnímal Lewis $(1981,116$ - 117) a totiž dodatočne vysvetl'ovat', že aktér nie je príčinou porušenia prírodného zákona.

Podobnú kompatibilistickú pozíciu o dva roky neskôr formuloval Fischer ${ }^{5}$ (1983):

\footnotetext{
${ }^{5}$ Toto však nebolo posledné slovo Fischera k téme determinizmu a slobodnej vôle. Neskôr formuloval pozíciu semikompatibilizmu (napríklad Fischer 2007).
} 
Som schopný urobit' niečo také, že ak by som to urobil, minulost' by bola iná, ako je (Fischer 1983, 131). ${ }^{6}$

Fischer o vnorenom kontrafaktuále hovorí, že ide o „neškodný, nekauzálny kontrafaktuál" (tamže). Uvedeným komentárom zdôrazňuje, že nie je pravda, že aktér mohol zmenit' minulost'. To je schopnost', ktorú zrejme žiadny aktér nemá. Aký je teda význam uvedeného kontrafaktuálu? Tento kontrafaktuál je podl'a všetkého len skratkou nasledujúceho úsudku: ak je pravda, že z konjunkcie propozície, ktorá vyjadruje stav sveta $\mathrm{v}$ nejakom minulom okamihu, a propozície, ktorá vyjadruje prírodné zákony, vyplýva, že aktér má ruku na stole, tak ak prijmeme kontrafaktuálny predpoklad, že ju na stole nemá, tak musíme zamietnut' prinajmenšom jeden z uvedených konjunktov. Lewis sa od Fischera odlišuje predovšetkým výberom zamietnutého konjunktu.

A zdá sa, že predpoklad o irelevantnosti toho, ktorý z konjunktov zamietneme, prijal Saunders (1986). Podla Saundersa aktéri majú

... schopnost' konat' tak (vykonat' niečo také, že ak by to bolo vykonané), že bud' by minulost' bola iná, ako bola, alebo by boli iné prírodné zákony, ako boli (Saunders 1986, 103).

Saundersov vnorený kontrafaktuál sa od Lewisovho a Fischerovho najnápadnejšie odlišuje v tom, že má v konzekvente disjunkciu. A je to disjunkcia konzekventov Fischerovho a Lewisovho vnoreného kontrafaktuálu, respektíve konzekventu pozmenenej verzie Lewisovho vnoreného kontrafaktuálu. $Z$ týchto troch uvedených prístupov je Saundersov najvšeobecnejší.

Dovol'te mi na chvílu sa vrátit' ku kondicionálnej analýze a objasnit' jej vzt'ah k uvedeným prístupom. Kondicionálna analýza je špeciálnym prípadom Fischerovho prístupu. Podl'a Punčochářa by sa v kontrafaktuálnej situácii, v ktorej sa aktér rozhodol konat' inak, ako v skutočnosti konal, muselo predpokladat', že tento aktér by mal aj inú motiváciu $(2017,624)$. To je pochopitel’né, pretože motivácia je relevantným parametrom vysvetlenia aktérovho konania - bolo by zvláštne predpokladat', že rovnaká motivácia by mohla stát za dvoma úplne odlišnými konaniami. No ak je determinizmus pravdivý, mali by sme tiež predpokladat', že d’alšia podmienka v predchádzajúcom okamihu by bola iná ako bola, ak by bola iná motivácia atd'. $Z$ toho vyplýva, že ak je pravda, že aktér mohol konat' inak v zmysle podmienkovej analýzy, tak mal schopnost' konat' tak, že ak by tak konal, minulost' by bola iná, ako bola.

\footnotetext{
${ }^{6}$ Toto nie je citácia, ale parafráza. Formát citácie som zanechal v záujme jednoduchšieho porovnania predkladaných pozícií.
} 
Povedal som, že podmienková analýza je len špeciálnym prístupom kompatibilizmu zmeny minulosti. A práve toho, v čom podmienková analýza hovorí viac ako kompatibilizmus zmeny minulosti, sa týkajú kritiky, ktoré sú vo všeobecnosti považované pre podmienkovú analýzu za fatálne. Kritické poznámky sú zvyčajne uvedené protipríkladom a literatúra ich v súčasnosti pozná vel'ké množstvo. Na ilustráciu si uved’me príklad, ktorý spomína Michael Fara (2008).

Napríklad Alica má neurózu a bojí sa pavúkov. Jej neuróza je natol'ko silná, že by v žiadnom prípade nemohla vedome vydržat' $v$ jednej miestnosti s pavúkom, nieto sa ho dotknút'. Takže Alica sa nemôže pokúsit' zdvihnút pavúka. Ale Alica je silná a obratná, rovnako ako všetci ostatní, takže keby skúsila, čo je nemožné, zdvihnút' pavúka, uspela by $(2008,851)$.

Podl’a tohto príkladu podmienková analýza zlyháva, pretože pripisuje aktérom schopnosti, ktoré zrejme nemajú. Antecedent kontrafaktuálu Ak by Alica skúsila zdvihnút pavúka, zdvihla by ho, je pravdivý v takých kontrafaktuálnych podmienkach, ktoré sú nezlučitel'né s Alicinou neurózou.

Kompatibilisti museli čelit' výzve prekonat' nedostatky podmienkovej analýzy. Tí, čo sa o to pokúsili, bývajú bežne označovaní ako Noví dispozicionalisti, pretože analyzujú schopnosti v termínoch dispozícií. Podl’a Fara $(2008,848)$ nevyhnutnou podmienkou schopnosti zdvihnút' pavúka je to, že Alica má dispozíciu zdvihnút' pavúka. A tú zrejme nemá. Podobne dôvodí aj Vihvelin (2013). Podl’a Vihvelin sú schopnosti zväzky (bundles) dispozícií (tamže, 170) a mat' dispozíciu znamená mat' vnútorné vlastnosti, ktoré sú kauzálnym základom schopnosti (tamže, 175). A Alici chýbal práve tento vnútorný kauzálny základ.

Verím, že tu prezentované kompatibilistické pozície dovedna predstavujú reprezentatívnu vzorku, ak nie vyčerpávajúci prehl'ad typov pozícií kompatibilizmu. Ak je to pravda, tak sme oprávnení prejst' ku všeobecnému komentáru a k neformálnej rekonštrukcii obhajoby kompatibilizmu pred argumentom následku.

Podl'a kompatibilizmu aktérov o schopnosti nepripravuje to, že ich nerealizujú, a dokonca ani to, že ich v istom zmysle slova nemohli realizovat'. Ak platí, že schopnost' aktéra $a$ urobit' $A$ nás oprávňuje k tvrdeniu, že aktér $a$ môže vykonat' $A$, tak potom platí, že $a$ mohol vykonat' $A$ aj v takom prípade, ked' svoju schopnost' vykonat' $A$ nerealizoval, respektíve ked' ju v istom zmysle slova realizovat' nemohol, pretože jej realizácia by znamenala porušenie prírodného zákona, respektíve zmenu minulosti. 
Takže nie je pravda, že ak je determinizmus pravdivý, tak nik nemôže konat' inak, ako v skutočnosti koná. ${ }^{7}$

V d'alšej časti sa budem venovat' porovnávaniu podmienok, ktoré podla kompatibilizmu, respektíve inkompatibilizmu musí aktér splnit', aby mal schopnost' konat' inak. Je dôležité overit' si, či kompatibilisti, respektíve inkompatibilisti rozumejú pod schopnost'ou konat' inak to isté alebo nie, pretože keby mali iný pojem schopnosti konat' inak, pripomínala by ich diskusia spor l'udí, ktorí sa nezhodnú v tom, že Miro je najmúdrejší žiak šiestej triedy, až kým si neuvedomia, že na identifikáciu takého žiaka používajú iné kritériá. Timothy O'Connor (2018) hovorí, že výraz „schopnost' konat' inak“ je významovo viacznačný, alebo vágny, pretože rôzni autori rozumejú výrazu „schopnost““ inak. Nazdávam sa, že O’Connor nemá pravdu. Nemá ju preto, lebo schopnost' konat' inak nie je nejaký osobitý druh schopnosti medzi ostatnými schopnost'ami, ale je to pojem, respektíve vlastnost' schopností. Keby mal O'Connor pravdu, museli by sme najprv presne definovat' pojem schopnosti, aby sme vôbec mohli povedat', čo to schopnost' konat' inak je. V takom prípade by sa ale mohlo namietat', že náš prístup nie je nestranný. No podl'a mojej mienky neplatí, že odpoved' na otázku, čo je to schopnost', ovplyvňuje odpoved', alebo nejako hlbšie súvisí s odpoved'ou na otázku, čo je to schopnost' konat' inak.

\section{O schopnosti konat' inak}

Byt'schopnostou konat' inak je status, ktorý schopnosti v čase získavajú a strácajú. To, či nejaká schopnost' získa status byt'schopnost'ou konat' inak, je kontextovo podmienené. Ak napríklad aktér beží, tak používa svoju schopnost' behat'. Ak má, kým behá, nejakú inú schopnost', ktorej použitie je nezlučitel’né s behaním, napríklad schopnost' chodit', tak má schopnost' so statusom schopnost' konat' inak. Čiže aktér má schopnost' konat' inak. No ak prestane bežat' a začne chodit', tak potom už schopnost' chodit' nie je schopnost'ou aktéra konat' inak ako koná, hoci neprestáva byt' aktérovou schopnost’ou. Nevyhnutnou podmienkou tvrdenia, že nejaký aktér má schopnost' konat' inak ako koná, alebo že mal schopnost' konat' inak ako konal, je, že tento aktér má, respektíve mal aspoň dve také schopnosti, ktoré nemožno uplatnit' zároveň a z ktorých jednu používa, respektíve použil. Verím, že kompatibilista ani inkompatibilista by nenamietali, že toto musí byt' pravda, aby aktér mal schopnost' konat' inak ako koná. Predpokladajme, že aktér beží. Ktorú schopnost' za tejto okolnosti označuje výraz „schopnost' aktéra, ktorý teraz beží, konat' inak, ako koná“? Ak má tento aktér v danom čase

\footnotetext{
${ }^{7}$ Jadro tejto obhajoby je podobné ako u Vihvelin $(2013,170$ - 171), ale tu uvedená obhajoba je všeobecnejšia.
} 
viac ako jednu schopnost', ktorej vykonanie je nezlučitel'né s vykonaním aktuálne vykonávanej schopnosti, tak všetky majú status byt' schopnost'ou aktéra konat' inak ako koná. Ak napríklad tento aktér má okrem schopnosti bežat' aj schopnost' sediet', stát' na mieste, schopnost' l'ahnút' si a schopnost' chodit', tak každá jedna z týchto schopností je jeho schopnost'ou konat' inak, ako práve koná. Takže výraz „schopnost' konat' inak" relatívne k tomuto aktérovi a za týchto podmienok neoznačuje schopnost', ale označuje množinu jeho schopností. A žiadna množina nie je schopnost'. To, čo označuje výraz „schopnost' konat' inak“ závisí od okolností. A mnohé schopnosti, ktoré máme, v čase získavajú a strácajú tento status. Ak povieme, že aktér nemal na výber vo vzt’ahu k nejakému konaniu, tak to znamená, že výraz „schopnost' konat' inak“ za daných okolností a vo vzt’ahu $\mathrm{k}$ danému aktérovi označuje prázdnu množinu. Medzi vlastnost'ou byt' schopnost'ou konat' inak a schopnost'ami je rovnaký vzt'ah ako medzi aktérmi a vlastnost'ou byt' prezidentom. Niektorí aktéri túto vlastnost' získajú, a potom ju stratia.

Takže byt' schopnost'ou konat' inak je pojem, ktorý označuje množinu takých schopností, ktorých uplatnenie je nezlučitel'né s uplatnením schopnosti, ktorú aktér uplatňuje. ${ }^{8}$ Hodnota tohto pojmu, totiž množina schopností, ktorú označuje, je relatívna k parametru aktéra, k parametru aktuálne použitej schopnosti, a vždy je podmnožinou všetkých schopností, ktoré daný aktér v čase konania má. Inak povedané, byt' schopnost'ou aktéra konat' inak ako koná, je funkcia z množiny usporiadanej dvojice aktér / konanie do takej množiny schopností, ktorá je vlastnou podmnožinou množiny všetkých schopností aktéra, na ktorého je táto funkcia aplikovaná. Preto sa hodnota tohto pojmu môže líšit' v prípade dvoch aktérov, ktorí práve bežia - jeden totiž môže mat' schopnost', ktorú druhý aktér nemá, napríklad schopnost' chodit' po rukách.

Mat'schopnost' konat' inak je vlastnost', ktorú pripisujeme aktérovi iba vtedy, ak aspoň jedna jeho schopnost' je schopnost'ou konat' inak. A nazdávam sa, že všetko, čo kompatibilisti tvrdia, je, že aktér má schopnost' konat' inak vtedy a len vtedy, ked' niektoré jeho schopnosti sú v čase jeho konania schopnostami konat' inak. Podl'a Lewisa, Fischera a Saundersa aktér, ktorý mal ruku na stole, mal schopnost' konat' inak, ak je pravda, že mal schopnost' zdvihnút' ruku, hoci je aktuálne vykonanie tejto schopnosti nezlučitel'né so zákonmi aktuálneho sveta, respektíve s minulost’ou aktuálneho sveta. Rovnaký zámer mali aj predstavitelia podmienkovej analýzy, ktorej nedostatky sa neskôr usilovali napravit' Noví dispozicionalisti. Spomeňme si na to, čo hovoril Moore o prejdení jednej míle za dvadsat minút a prebehnutí dvoch míl' za pät' minút' - ak som neurobil ani jedno, tak ak je determinizmus pravdivý, v istom zmysle slova som ani jedno urobit' nemohol. Ale $\mathrm{v}$ inom slova zmysle som mohol urobit' jedno, kým druhé nie. Inak povedané, ani jedno

${ }^{8}$ Tu predpokladám, že uplatnenie schopnosti (konanie) je jedinečná a neopakovatel'ná udalost', ktorá sa vyskytuje na nejakom mieste a v nejakom čase. 
nemohol Moore $\mathrm{v}$ istom zmysle slova vykonat', hoci jedno z nich mohol, respektíve mal schopnost' vykonat'. A to, že mal túto schopnost' v čase, ked' pil kávu alebo raňajkoval, znamená, že mal schopnost' konat' inak.

Je zaujímavé, kol'ko nedorozumení vyvolala identifikácia vlastnosti aktéra mat' schopnost' konat' inak s jeho schopnost'ami. Úsilie kompatibilistov schopnosti konat' inak a determinizmu je vlastne úsilím preukázat' to, že nestrácame schopnosti, ktorých použitie je nezlučitel'né s aktuálne používanou schopnost'ou. Ale inkompatibilista netvrdí, že ak je pravdivý determinizmus, tak prichádzame o nejaké schopnosti, ale že žiadne aktuálne nevyužité schopnosti nemajú status byt' schopnostou konat' inak. To potvrdzuje aj libertarián Richard Taylor $(1963,497)$, ked' sa bráni kritike oponentov jeho argumentu v prospech fatalizmu, ktorý formuloval, aby dokázal nezlučitel’nost' princípu bivalencie so slobodnou vôlou:

... kritici poukazujú na to, že máme schopnost' urobit' niečo, aj ked' chýba nejaká podmienka - minulá, prítomná, budúca - nevyhnutná na jej použitie. Čiže niekto môže byt' dokonale schopný plávat', hoci nie je práve pri jazere, alebo môže zdvihnút' závažie, hoci sa o to nepokúsi, alebo dat' diet'at'u na zadok väčšmi, než si zaslúži, a tak d'alej. Toto všetko je dokonale pravdivé (Taylor 1963, 497).

Taylor so svojimi kritikmi plne súhlasí, ked' hovoria, že determinizmus nás neoberá o žiadne schopnosti. Taylor a d’alšś inkompatibilisti sa usilujú dokázat', že ak je determinizmus pravdivý, tak žiadna naša schopnost' nikdy nemá status byt' schopnost'ou konat' inak ako konáme.

Kompatibilista je presvedčený, že aktér má schopnost' konat' inak vtedy a len vtedy, ked' má d’alšie schopnosti, ktoré splńnajú určité podmienky. Čo si myslí inkompatibilista? Za akých podmienok možno povedat', že aktér má schopnost' konat' inak, ako konal? Je zaujímavé, že hoci môžeme v literatúre nájst' mnoho podôb kompatibilizmu, nič také nemôžeme povedat' o inkompatibilizme. Najlepšie vysvetlenie asi je, že inkompatibilista je ten, kto začína celú diskusiu, a je na kompatibilistovi, aby vypracoval nejakú pozitívnu odpoved' a doložil k nej vysvetlenie. Nazdávam sa, že inkompatibilista podmieňuje pripísanie vlastnosti mat'schopnost' konat' inak, ako koná, aktérovi ešte splnením d’alšej podmienky. Stopy tejto podmienky môžeme nájst' napríklad v texte Roberta Kanea:

Podla vašej analýzy môžu osoby preskočit' plot, hoci je to tu a teraz nemožné vzhl'adom na minulost' a prírodné zákony. To nie je to ako my, 
libertariáni, rozumieme výrazu „môct"“ $\mathrm{v}$ argumente následku. Rozumieme mu tak, že je možné, že to urobite tu a teraz, vzhl'adom na všetky fakty, ktoré sa v pritomnosti vyskytujú (Kane 2007, 13). ${ }^{9}$

Kane na tomto mieste oslovuje kompatibilistov podmienkovej analýzy. Je dôležité všimnút' si výraz ,je možné“ v citácii. Tento výraz neodkazuje na schopnost', ale na historickú možnost'. Historické možnosti sú konceptuálne naviazané na doktrínu indeterminizmu, podl'a ktorej sú minulost' a prítomnost' zlučitel'né s odlišnými budúcnost’ami. Tento druh indeterminizmu bežne voláme otvorená budúcnost' a modelujeme ho tak, že na množine stavov sveta definujeme reláciu čiastočného usporiadania, pre ktorú platí podmienka spätnej, teda do minulosti orientovanej lineárnosti, ktorá nemá korešpondujúcu podmienku pre budúcnost', pretože tá pozostáva $\mathrm{z}$ viacerých možných, s aktuálnou minulost'ou zlučitel'ných budúcností. Medzi týmito budúcnost'ami nenájdeme žiadnu aktuálnu budúcnost', v porovnaní s ktorou by ostatné boli len čírymi možnost’ami - všetky sú rovnako možné a žiadna z nich zatial' nie je aktuálna. Preto pre model jazyka nad touto štruktúrou neplatí princíp bivalencie - sú také výroky, ktoré nie sú ani pravdivé, ani nepravdivé, výroky ako „Zajtra bude námorná bitka“"10 a podobne. $Z$ ontologického hl'adiska sa minulost' zväčšuje, časom narastá, ale to, ktorá budúcnost' bude aktualizovaná, respektíve ktorá z možných budúcností sa časom stane aktuálnou minulost'ou, čiastočne záleží aj od slobodných aktérov, ktorých rozhodnutia možno opísat' ako vylučovanie niektorých z možných budúcností z pozície kandidátov na aktuálnu minulost'. Tento druh indeterminizmu, indeterminizmus otvorenej budúcnosti, vychádza naproti niektorým našim bežným očakávaniam, totiž že budúcnost' ešte nie je daná a že to, ktorá nastane, aspoň čiastočne závisí od našich rozhodnutí. A inkompatibilista trvá na tom, že aktér má schopnost' konat' inak ako koná, iba ak je indeterminizmus pravdivý, pretože podmienkou tejto schopnosti je, že alternatívne konanie k aktuálne používanej schopnosti musí, alebo aspoň raz muselo byt' historickou možnost'ou. Čiže ak aktér beží, tak potom má, respektíve mal schopnost' konat' inak ako koná, respektíve konal, iba ak je, alebo ak bolo historicky možné, že bude chodit', sediet' alebo plávat' a podobne. Inak povedané, aktér má schopnost' konat' inak ako koná, iba ak je taký nedávny okamih, v ktorom nebola pravda, že behat' bude, ale ani to, že nebude.

\footnotetext{
${ }^{9}$ Kane tu formuluje odpoved' kompatibilistom a hovorí v mene obhajcov argumentu následku, špeciálne libertariánov.

${ }^{10}$ Typ výrokov, o ktorých sa tu zmieňujem, je v angličtine označovaný ako future contingents propositions. V slovenčine zatial' nemáme ustálený ekvivalent názvu tohto typu propozícií. Ponúkajú sa možnosti ako budúce náhodné propozície alebo kontingentné propozície o budúcnosti. Príklad s námornou bitkou použil už Aristoteles. Explicitne o princípe bivalencie a o potrebe jeho zamietnutia, ak je determinizmus nepravdivý, hovoril Jan Łukasiewicz $(1990,126)$
} 
Predpokladám, že inkompatibilista súhlasí s kompatibilistovou požiadavkou, že aktér, ktorý má schopnost' konat' inak, musí mat' okrem použitej schopnosti aj nejaké iné schopnosti. Inkompatibilista však dodáva, že táto požiadavka nie je dostatočnou podmienkou pre pripísanie schopnosti konat' inak aktérovi, pretože je ešte aspoň jedna nevyhnutná podmienka, a totiž, že alternatívne konanie muselo byt' historickou možnost'ou. A ak táto podmienka nebola splnená, tak potom podl'a inkompatibilistu všetky d’alšie schopnosti, ktoré aktér aktuálne nepoužíva, strácajú status byt'schopnostou konat' inak.

Na začiatku práce som povedal, že sa k pojmu determinizmu a k jeho definícii ešte krátko vrátim. Sú prinajmenšom dva postupy definovania determinizmu a negácia výsledku jednej z nich nevedie $\mathrm{k}$ indeterminizmu, ktorý je pre libertariána použitel'ný. Na odlišnost'v týchto definíciách upozorňujú Müller a Placek (2018) a Müller et al. (2019). Podl'a jedného postupu definovania determinizmu je deterministický svet taký v ktorom absentuje vetvenie. A ak svet nie je deterministický, tak sa v nejakom okamihu vetví - pozostáva z viac ako jednej histórie, ktoré sa v nejakom intervale prekrývajú. Podl'a druhého postupu definovania determinizmu je svet deterministický vtedy a len vtedy, ked' pre každý možný svet, v ktorom platia rovnaké prírodné zákony ako v aktuálnom svete platí, že ak sa s aktuálnym svetom zhoduje aspoň v jednom okamihu, tak sa s ním zhoduje vo všetkých okamihoch. Earman $(1986,13)$ zhodu svetov v nejakom okamihu vysvetl'uje tak, že tieto svety majú v danom okamihu všetky fyzikálne vlastnosti rovnaké. Čiže dané svety sú v nejakom čase kvalitatívne identické, ale numericky odlišné, neprekrývajú sa, a teda sa ani nevetvia. Negácia determinizmu potom znamená, že existuje aspoň jeden taký možný svet, ktorého prírodné zákony sú rovnaké ako prírodné zákony aktuálneho sveta a tento svet je s aktuálnym svetom aspoň $v$ jednom okamihu kvalitatívne identický, no existuje aspoň jeden taký okamih, $\mathrm{v}$ ktorom sa tieto svety odlišujú. V jazyku opisujúcom takýto indeterministický svet platí princíp bivalencie - budúcnost' nie je otvorená. V nejakom zmysle slova je pravda, že to, čo sa stane, stane sa. V tomto svete však viac nie je nevyhnutnost', ktorá by nám umožnila spoliehat' sa na predpovede javov a ich vysvetlenia. Nie je v ňom prítomná invariantnost' $\mathrm{v}$ nasledovaní určitých príčin určitými následkami. Bolo by zvláštne, ba až nepochopitel'né tvrdit', že takýto svet je vhodným miestom pre aktéra so slobodnou vôlou. Takýto indeterministický svet libertariánovi nič nedáva, za to mu mnohé berie.

Poznámkou k dvom postupom definovania determinizmu sledujem dva ciele: 1) Inkompatibilista prijíma postup definovania determinizmu, ktorý nie je prijímaný vo všeobecnosti; 2) Je škoda, že autori, ktorí píšu o kompatibilite determinizmu a slobodnej vôle, často začínajú svoje práce pomerne skromným a nešpecifickým komentárom k determinizmu, v ktorom sa zmieňujú o princípe kauzality, o nevyhnutnosti, 
s akou nasleduje účinok svoju príčinu, o nekonečne dlhých kauzálnych ret’azcoch alebo nezlučitel’nosti minulosti s viacerými možnými budúcnost’ami. Ak totiž niekto prijíma z nezávislých dôvodov druhý uvedený postup definovania determinizmu, tak by jeho stanovisko k problematike zlučitel'nosti determinizmu a slobodnej vôle malo byt' zrejmé ešte skôr, ako preň začne uvádzat' vysvetlenia.

\section{Záver}

V práci som sa pokúsili poukázat' na viaceré nedorozumenia medzi kompatibilistami a inkompatibilistami. Prvé nedorozumenie spočívalo v nesprávnej interpretácii záveru a ciel'a argumentu následku - kompatibilisti boli presvedčení, že ak je argument následku platný a ak je determinizmus pravdivý, prichádzame o množstvo našich schopností. Preto vo svojej obhajobe dokazujú, že z predpokladu o pravdivosti determinizmu nevyplýva, že nejaké schopnosti strácame. Ciel’om inkompatibilistov pritom bolo poskytnút' dôkaz, podla ktorého nás determinizmus nepripravuje o schopnosti, ale pripravuje naše schopnosti o status byt' schopnost'ou konat' inak.

Toto nedorozumenie vysvetlujem tak, že kompatibilisti a inkompatibilisti majú iný pojem schopnosti konat' inak. Ak je to pravda, tak diskusia medzi kompatibilizmom a inkompatibilizmom je $\mathrm{v}$ zvláštnom stave. Na začiatku práce som rozlíšil striktných inkompatibilistov, libertariánov, kompatibilistov, podl’a ktorých je determinizmus zlučitel'ný so schopnost’ou konat' inak, a takých kompatibilistov, ktorí sa hlásia k pojmu slobodnej vôle, ktorý nepredpokladá, že aktéri majú schopnost' konat' inak. Ktoré $\mathrm{z}$ týchto táborov si naozaj odporujú $\mathrm{v}$ tom, že slobodná vôl'a a determinizmus sú zlučitel'né? Zdá sa, že žiadne.

\section{Literatúra}

FARA, M. (2008): Masked Abilities and Compatibilism. Mind, 117 (468), 843 - 865.

FISCHER, J. M. (1983): Incompatibilism. Philosophical Studies, 43 (1), 127 - 137.

FISCHER, J. M. (2007): Compatibilism. In Four Views on Free Will. Malden - Oxford: Blackwell Publishers Blackwell $(5-43)$.

FOLEY, R. (1979): Compatibilisim and and Control over Past. Analysis, 39 (2), 70 - 74.

FRANKFURT, H. G. (1069): Alternate Possibilities and Moral Responsibility. Journal of Philosophy, 66 (23), $829-839$.

KANE, R. (2007): Libertarianism. In: Four Views on Free Will. Malden - Oxford: Blackwell Publishers, $5-43$.

LEWIS, D. (1981): Are we free to break the laws? Theoria, 47 (3), $113-121$.

LEWIS, D. (1987): Philosophical Papers: Volume II. Oxford: Oxford University Press.

ŁUKASIEWICZ, J. (1990): On Determinism. In: Borkowski, L. (ed.): Selected Works. Studies in Logic and the Foundations of Mathematics. Amsterdam - London: Nort Holland, 110 - 128.

MARKO, V. (2017): Towards a Demarcation of Forms of Determinism. Organon F, 24 (1), 54 - 84.

MOORE, G. E. (1912): Ethics. Oxford: Oxford University Press.

MÜLLER, T., PLACEK, T. (2018): Defining Determinism. British Journal for the Philosophy of Science, 69, 215 - 252. DOI: https://doi.org/10.1093/bjps/axv049 
MÜLLER, T., RUMBERG, A.; WAGNER, V. (2019): An introduction to real possibilities, indeterminism, and free will: three contingencies of the debate. Synthese, 196 (1), 1 - 10. DOI https://doi.org/10.1007/s11229-018-1842-4

O’CONNOR, T. (2018). Free will. Stanford Encyclopedia of Philosophy. Dostupné na: $<$ https://plato.stanford.edu/entries/freewill/ >

PEREBOOM, D. (2007). Hard Incompatibilism. In Four Views on Free Will. Hoboken - New Jersey: Willey Blackwell.

PUNČOCHÁŘ, V. (2017). Problém svobodné vůle a logika kontrafaktuálních výroků. Filosofický časopis, 65 (4), $607-631$.

SAUNDERS, J. T. (1968): The Temptations of "Powerlessness". American Philosophical Quarterly, 5 (2), $100-108$.

TAYLOR, R. (1963): A note on fatalism. Philosophical Review, 72 (4), 497 - 499.

VAN INWAGEN, P. (1975): The Incompatibility of Free Will and Determinism. Philosophical Studies, 27 (3), $185-199$

VAN INWAGEN, P. (1986): An Essay on Free Will. Oxford: Oxford University Press.

VIHVELIN, K. (2013): Free Will Demystified: A Dispositional Account. In: Russell, P - Deery, O. (eds.): The Philosophy of Free Will: Essential Readings From the Contemporary Debates, 166 - 189. DOI: 10.5840/philtopics2004321/211

Táto práca bola podporená projektom Agentúry pre podporu výskumu a vývoja č. APVV-17-0057 a grantom VEGA č. 1/0036/17.

Tomáš Kollárik

Katedra logiky a metodológie vied

Filozofická fakulta UK v Bratislave

Gondova 2

81499 Bratislava

Slovenská republika

e-mail: tomas.kollarik@uniba.sk

ORCID ID: https://orcid.org/0000-0002-8354-7970 